\title{
Cryoablation decreases platelet reactivity in patients with atrial fibrillation compared with radiofrequency ablation: results from the Sparelife Project
}

\section{Jure Samardžić*, Vedran Velagić, Boško Skorić, Saša Pavasović, Marijan Pašalić, Hrvoje Jurin, Olvo Planinc, Maja Čikeš, Davor Puljević, Davor Miličić}

University of Zagreb School of Medicine, University Hospital Centre Zagreb, Zagreb,

Croatia
KEYWORDS: atrial fibrillation, pulmonary vein isolation, platelet reactivity. CITATION: Cardiol Croat. 2017;12(9-10):375. | https://doi.org/10.15836/ccar2017.375

*ADDRESS FOR CORRESPONDENCE: Jure Samardžić, Klinički bolnički centar Zagreb, Kišpatićeva 12, HR-10000 Zagreb, Croatia. / Phone: +385-98-537-864 / E-mail: jure.samardzic@gmail.com

ORCID: Jure Samardžić http://orcid.org/0000-0002-9346-6402 •Vedran Velagić http://orcid.org/0000-0001-5425-5840 Boško Skorić http://orcid.org/0000-0001-5979-2346 • Saša Pavasović http://orcid.org/0000-0002-3705-0226 Marijan Pašalić http://orcid.org/0000-0002-3197-2190 • Hrvoje Jurin http://orcid.org/0000-0002-2599-553X Ivo Planinc http://orcid.org/0000-0003-0561-6704 • Maja Čikeš http://orcid.org/0000-0002-4772-5549 Davor Puljević http://orcid.org/0000-0003-3603-2242• Davor Miličić http://orcid.org/0000-0001-9101-1570

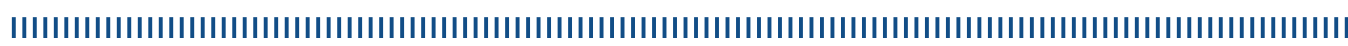
Introduction: Pulmonary vein isolation (PVI) procedures increase the potential thromboembolic risk. ${ }^{1}$ The aim of this study was to compare the effect of radiofrequency (RF) ablation and cryoablation on platelet reactivity $(\mathrm{PR})$ in patients with atrial fibrillation (AF).

Patients and Methods: We analyzed PR levels using Multiplate function analyzer in 63 consecutive patients undergoing PVI procedures in our institution. Blood samples were drawn just before the procedure and on the following day. Fourty six (46) and seventeen (17) patients underwent cryoablation and RF ablation, respectively. There was no difference in demographics and baseline platelet parameters (platelet count, MPV and PR) between patients in RF and cryo group. ASPI, ADP and TRAPtest were used to --assess multiple pathways of platelet activation.

Results: One day after the procedure mean PR droped from baseline levels in both study groups. The observed delta was more expressed in the cryo group for all three PR tests but only ADPtest showed statistically significant difference in PR (Figure 1).
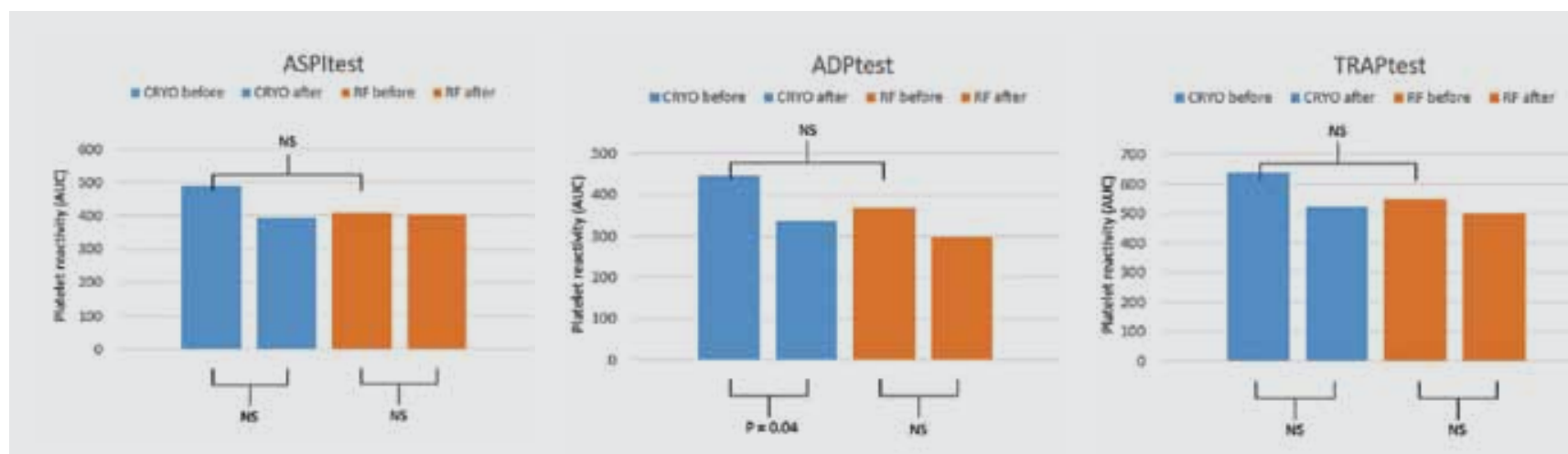

FIGURE 1. Platelet reactivity before and after pulmonary vein isolation.

$\mathrm{RF}=$ radiofrequency

RECEIVED:

September 24, 2017

ACCEPTED:

September 26, 2017

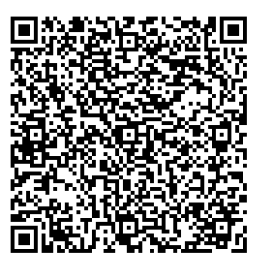

Conclusion: Our results show that PR after cryoablation is less pronounced compared to RF procedure. This affirms that thrombogenic burden of PVI is lower with cryoablation. We hypothesize that this could be a result of endocardial integrity preservation and decreased availability of platelet agonists during cryoablation. These results warrant further investigations with periinterventional PR measurements on a larger cohort of patients.

Aknowledgement: This study was funded by Croatian Science Foundation.

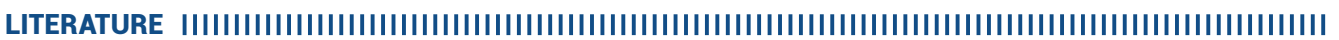

1. Tse HF, Kwong YL, Lau CP. Transvenous cryoablation reduces platelet activation during pulmonary vein ablation compared with radiofrequency energy in patients with atrial fibrillation. J Cardiovasc Electrophysiol. 2005 0ct:16(10):1064-70. https://doi.org/10.1111/.1540-8167.2005.50103.x 